\title{
Analysis of the Themes and Artistic Features of For Whom the Bell Tolls
}

\author{
Yue Zuo \\ Foreign Language Department, Liaoning Technical University, Fuxin, China \\ Email: 215505348@qq.com \\ Received 4 February 2015; accepted 29 March 2015; published 31 March 2015 \\ Copyright (C) 2015 by author and Scientific Research Publishing Inc. \\ This work is licensed under the Creative Commons Attribution International License (CC BY). \\ http://creativecommons.org/licenses/by/4.0/

c) (i) Open Access

\begin{abstract}
Each of the characters in For Whom the Bell Tolls loses his or her psychological or physical innocence to the war. Some endure tangible traumas. The span of the story time only stays four days. The author has magnificently written tens of thousands of words and further details. When people have a problem, their minds are chaotic and think a lot of things. These thoughts are fragments, no rhyme. In this article, the author is trying to express this ambivalence intuitively so that the reader can enter the character's heart and appreciate the complex psychological characters.
\end{abstract}

\section{Keywords}

For Whom the Bell Tolls, Ernest Miller Hemingway, The War, The Love, Artistic Features

\section{Introduction}

Ernest Miller Hemingway was born in 1899 in a wealthy, conservative Chicago suburb. The second of six children, he showed an early talent in writing that he honed through work on his high school's literary magazine and student newspaper. Upon graduating from high school in 1917, Hemingway moved away from home and embarked on a professional writing career, starting as a reporter for the Kansas City Star. In 1918, during the height of World War I, Hemingway volunteered to serve as an ambulance driver for the Red Cross, which sent him to Italy. Within just a few weeks of his arrival, Hemingway was injured by an exploding shell and was sent to a hospital in Milan. During his recovery, he became romantically involved with a nurse_-an episode that he portrayed years later in his novel A Farewell to Arms (1929) (Baker, 1972). After the war, Hemingway worked as a newspaper correspondent in Paris, where he moved among a circle of expatriate artists and writers, including American writers F. Scott Fitzgerald and Gertrude Stein, Irish writer James Joyce, and Spanish painter Pablo Picasso. Stein, in particular, became Hemingway’s mentor.

Some critics have suggested that she provided the inspiration for the character Pillar in For Whom the Bell 
Tolls, who serves as a mother figure for the protagonist, Robert Jordan. During his time as a correspondent, Hemingway traveled extensively in Spain and developed a strong interest in Spanish culture. He became especially interested in bullfighting, which he viewed as a uniquely Spanish experience that accustomed Spaniards to face death and thus enabled them to live fuller lives. For Whom the Bell Tolls explores the wartime individuality, the effects of the war on it combatants and the military bureaucracy's indifference to human life (Baker, 1967).

In May 1937, at the height of the Spanish war. An American man called Robert Jordan, who left the United States to take part in the Republic side in the war, travel behind enemy lines to work with Spanish guerrilleros, hiding in the mountain. The Republic command has assigned Robert Jordan the dangerous and difficult task of blowing up a Fascist-controlled bridge as a part of a larger Republic offensive. At the camp, he meets Pilar, who is "woman" and treats Robert as his mother. During the evening, he meets six other inhabitants in the camp: the unreliable Rafael, feisty and foul-mouthed Augstin, dignified Fernando, old and righteous Primitivo, and brothers Andres and Eladio. The camp also shelters a young woman named Maria, whom a band of Fascists raped not long before. Robert and Maria are immediately drawn to each other. The "six other inhabitants" sacrifices their life for the task because the Fascists are too overwhelming compared with the Republic side. Pilar and Pablo lead Maria away. The finality for Robert is death, "feeling his heart beating against the floor of the forest".

In conclusion, the essay is divided into 5 sections, which are "Introduction", "Literature Review", "Themes", "Artistic Features" and "Conclusion". The themes of the work are "love from nature, return to nature, blend in nature and feel the natural magic". The perspective of "time", the space of "time" and other typical narrative techniques is making the novel present unique artistic features.

\section{Literature Review}

First, in 1973 from America, "Hemingway’s Spanish Tragedy" has reviewed: Spain is the pure land of his heart and his spiritual home. Bullfighting art inspired his literary creation inspiration, prompted him to form his simple and honest style of writing (Broer, 1973).

The next, in 2005 from China, "From observation 'For Whom the Bell Tolls' Hemingway's ecological and feminist consciousness" has introduced the themes of the work, such as harmony, relationships, love and so on. The author, Dai Guiyu, a doctor of literature, an assistant professor at Commercial English Faculty, Guangdong University of Foreign Studies, specializing in English and American literature (Dai, 2005).

Finally, from the two work, I have concluded the themes and artistic Features of For Whom the Bell Tolls. I think" For Whom the Bell Tolls" tells us that this kind of harmony is the most difficult things to struggle to feel consciousness, know themselves and the nature of relationships.

\section{Themes}

Themes are the fundamental and often universal ideas explored in a literary work. Each of the characters in For Whom the Bell Tolls loses his or her psychological or physical innocence to the war. Some endure tangible traumas: Joaquín loses both his parents and is forced to grow up quickly, while Maria loses her physical innocence when she is raped by a group of Fascist soldiers. On top of these tangible, physical costs of the war come many psychological costs. Robert Jordan initially came to Spain with idealism about the Republican cause and believed confidently that he was joining the good side. But after fighting in the war, Robert Jordan becomes cynical about the Republican cause and loses much of his initial idealism. The victims of violence in the war are not the only ones to lose their innocence- - the perpetrators lose their innocence too. The ruffians in Pablo's hometown who participate in the massacre of the town Fascists have to face their inner brutality afterward. Anselmo has to suppress his aversion to killing human beings, and Lieutenant Berrendo has to quell his aversion to cutting heads off of corpses. War even costs the innocence of people who aren't involved in it directly. War journalists, writers, and we as readers of novels like For Whom the Bell Tolls have to abandon our innocent expectation that wars involve clean moral choices that distinguish us from the enemy. Hemingway shows in the novel that morality is subjective and conditional, and that the sides of right and wrong are almost never clear-cut (Chang, 2003). With no definite sides of right and wrong in For Whom the Bell Tolls, there is no sense of glorious victory in battle, no sense of triumph or satisfaction that good prevails and evil is defeated.

Through the efforts to achieve a kind of balance of nature and man, man and woman, universal harmony between people, Hemingway told us that this kind of harmony is the most difficult things to struggle to feel consciousness, know themselves and the nature of relationships. Knowing yourself and others to create the fate of 
coexist is important. People should need to break the center consciousness and overcome and dominate the arrogant feeling so that cultivating "the feeling of love". In order to get love from nature, people should return to nature, blend in nature and feel the natural magic.

\section{Artistic Features}

The span of the story time only stays four days, the author has magnificently written tens of thousands of words and further details. When people have a problem, their minds are chaotic and think a lot of things. These thoughts are fragments, no rhyme. The author is very well in the language to express this ambivalence intuitively so that the reader can enter the character's heart and appreciate the complex psychological characters. This description technique is superb, which will let you follow characters' thoughts to develop in the book.

The author intends to the excellent eyesight to make the fate of the protagonist vividly and depict the story of the relationship between light and shade processing. Through the depth of the symbolism, the author wants to show the character of the complexity of the real world and the connotation of literary works (Freauman, 1937).

In For Whom the Bell Tolls, Hemingway effectively use the perspective "time" the space of "time" and other typical narrative technique, making his novels present unique artistic features. Hemingway also seems to be interested in the use of time and space when he is writing and create a sense of time and space on purpose. Thus, reading works in among them can feel the time bring us the sense of history. At the same time, readers also can feel the stereo feelings of the space and enhance the sense of reality and artistic appeals of his works.

\section{Conclusion}

This novel, which we can see is not only a fictional novel, but also different understanding about the Spanish culture and the effect of war on individual. The character he portrays in the novel owns their unique features, especially Pilar. Hemingway's depiction about the imagery also makes a deep impression on the reader which is full of symbolic meaning. This work is worthy to be read thoroughly.

\section{References}

Baker, C. (1972). Hemingway. The Writer as Artist. Princeton: Princeton University Press.

Baker, S. (1967). Earnest Hemingway: An Introduction and Interpretation. New York: Holt Rinehart and Winston.

Broer, L. (1973). Hemingway’s Spanish Tragedy. Tuscaloosa: University of Alabama Press.

Dai, G. Y. (2005). From Observation “For Whom the Bell Tolls” Hemingway’s Ecological and Feminist Consciousness.

Chang, Y. X. (2003). A Survey of American Literature. Tianjin: Nankai University Press.

Freauman, J. (1937). The Writer in A Changing World. New York: Equinox Cooperative Press. 